\title{
Analysis of Effect of "the Replacement of Business Tax by Value-Added Tax" in the Construction Industry and Suggestions
}

\author{
Xing Liu \\ North China Electric Power University, Beijing, China \\ ncepu_Ix@163.com
}

Keywords: Construction industry; Tax revenue; VAT.

\begin{abstract}
Purposes: This thesis demonstrates the effects of "the replacement of business tax by value-added tax (VAT)" on the construction industry and the results of this policy and put forward relevant suggestions. Methods: documentary analysis, statistical analysis. Results: There are many problems about the implementation of "the replacement of business tax by value-added tax", such as no specific regulations of the designation of tax payment places, a lack of VAT deduction chain between upstream and downstream enterprises, the great difficulty of tax supervision by the government, etc. Conclusion: The government should expedite the institutionalization of "the replacement of business tax by value-added tax" in the construction industry and expand the pilot scope in various regions and industries. It should also intensify the supervision over tax payment and management so as to improve the management level.
\end{abstract}

\section{Background and Theoretical Basis}

Background. VAT is collected on the added value in the commodity production, circulation, labor and service links but not on the cost in the intermediate link. Therefore, it is well-accepted worldwide for its characteristic of neutral tax. The business tax and VAT co-exist in China's current circulation tax system. However, as the product of the development of China's market economy system, it was identified as the main objective and task of the economic development that we should "accelerate the transformation of economic development pattern and restructure the domestic economy"[1]. The existing circulation tax system is found unreasonable somehow and exert an increasingly negative impact on the economy. Since the implementation of VAT in our country, there has been no complete tax deduction chain in the commodity production, circulation and other links, which caused problems like overlapping tax and tax injustice.

To tackle the problems caused by the existing tax system, which allows the co-existence of VAT and business tax, "CCCPC's advice on the formulation of the twelfth five-year plan for national economic and social development" was passed in CPC's fifth plenary session of the 17th Central Committee in October 18, 2010 and required "the expansion of the deduction scope of VAT and the according reduction of business and other taxes"[2]. Since November 16, 2011, when "The Pilot Program of the Replacement of Business Tax by VAT" was published after the stipulation by the State Committee, the relevant actions began.

Tax Incidence Theory. Tax incidence refers to the foothold of the tax burdens being transformed and is a kind of theoretical abstraction. If the transforming process of the tax burdens is to be analyzed in the enterprise and individual level, the tax incidence equals to tax barer [3]. From the economic aspect, the real tax barer may differ from the legal tax barer in real life. Graph 1 suggests the increase of tax burden in the society as a whole, but this burden is borne jointly by consumers and enterprises, and how much each party will bear is determined by the elastic curve. Through analyses, we can find that in the construction industry, the enterprises bare more burden than consumers, which is due to the greater elasticity of consumers. This is the invisible increase of tax burden of enterprises in the construction industry after "the replacement of business tax by value-added tax (VAT)". They may reduce some of the tax burden we can observe after the improvement of chains, but it is still subject to the specific situation of each enterprise whether this kind of burden reduction can offset the invisible burden increase. 


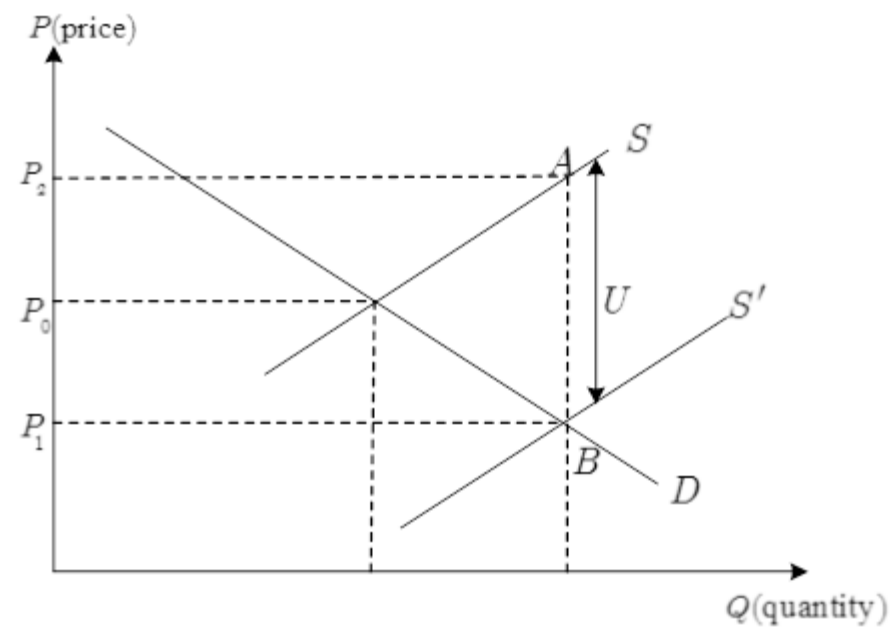

Figure 1. Tax Incidence Model

\section{Data Statistics and Analysis of Difficulties}

Data Statistics. I analyzed the contradictions between central and local tax revenue through the statistics of national tax revenue and fiscal expenditure in 2014. Utilizing method of statistical analysis, I calculated the tax data in construction industry before "the replacement of business tax by value-added tax (VAT)"(in 2005, 2007 and 2010), compared the tax effect of the business tax rate of $3 \%$ and that of the value-added tax rate of $11 \%$ and then worked out the impacts imposed by "the replacement of business tax by value-added tax" on the tax revenue in the construction industry.

Table 1 The national tax revenue and fiscal expenditure in 2014 after "the replacement of business tax by value-added tax "[4]

Unit: [hundred million yuan]

\begin{tabular}{|c|c|c|c|c|c|}
\hline Years & $\begin{array}{c}\text { total volume of } \\
\text { national tax revenue }\end{array}$ & $\begin{array}{c}\text { central-level tax } \\
\text { revenue }\end{array}$ & $\begin{array}{c}\text { percentage of central } \\
\text { tax revenue }\end{array}$ & $\begin{array}{c}\text { local tax } \\
\text { revenue }\end{array}$ & $\begin{array}{c}\text { percentage of local } \\
\text { tax revenue }\end{array}$ \\
\hline tax revenue & 103768 & 44973 & $43.3 \%$ & 58795 & $56.7 \%$ \\
\hline $\begin{array}{c}\text { fiscal } \\
\text { expenditure }\end{array}$ & 151662 & 22570 & $14.9 \%$ & 129092 & $85.1 \%$ \\
\hline
\end{tabular}

VAT is the most important circulation tax in China. Under the former tax revenue sharing mechanism, VAT in export section was included by central tax revenue while in domestic section shared by central and local governments at a rate of 75:25. Except the part concentrated-paid by the railway corporation and the head offices of various banks, all other business tax went to local governments. After "the replacement of business tax by value-added tax" in construction industry, the business tax that used to be paid solely to the local government were transformed into VAT shared by central and local governments, which reduced the local tax revenue to a great extent. Table 1 indicates that in 2014, the central tax revenue took up $43.3 \%$ of the total volume of national tax revenue and the local government $56.7 \%$. However, in terms of fiscal expenditure, the central government accounted for $14.9 \%$, while the local government $85.1 \%$. Imbalance between fiscal revenue and expenditure aggravated the contradiction between the central and local government and make it difficult for "the replacement of business tax by value-added tax" to go further. 
Table 2 The amount of business tax in construction industry before "the replacement of business tax by value-added tax"

Unit:[hundred million yuan]

\begin{tabular}{|c|c|c|c|}
\hline Years & $\begin{array}{c}\text { total output of construction industry } \\
\text { in China }\end{array}$ & $\begin{array}{c}\text { business tax rate for the construction } \\
\text { industry }\end{array}$ & $\begin{array}{c}\text { the amount of payable } \\
\text { business tax }\end{array}$ \\
\hline 2005 & $34,552.10$ & $3 \%$ & $1,036.56$ \\
\hline 2007 & $51,043.71$ & $3 \%$ & $1,531.31$ \\
\hline 2010 & $96,031.13$ & $3 \%$ & $2,880.93$ \\
\hline
\end{tabular}

Table 3 The impacts of "the replacement of business tax by value-added tax" in construction industry on the fiscal revenue in China[4]

\begin{tabular}{|c|c|c|c|c|c|c|}
\hline Years & $\begin{array}{c}\text { the amount of } \\
\text { payable VAT } \\
\text { after "the } \\
\text { replacement of } \\
\text { business tax by } \\
\text { value-added tax" }\end{array}$ & $\begin{array}{c}\text { the amount of } \\
\text { tayable business } \\
\text { replacement of } \\
\text { business tax by } \\
\text { value-added tax" }\end{array}$ & $\begin{array}{c}\text { the increased } \\
\text { amount of } \\
\text { input VAT } \\
\text { deduction } \\
\text { from services } \\
\text { for other } \\
\text { industries }\end{array}$ & $\begin{array}{c}\text { the reduced } \\
\text { amount of } \\
\text { circulation tax } \\
\text { after "the } \\
\text { replacement of } \\
\text { business tax by } \\
\text { value-added tax" }\end{array}$ & $\begin{array}{c}\text { the reduced and } \\
\text { increased amounts } \\
\text { of enterprise } \\
\text { income tax after } \\
\text { "the replacement } \\
\text { of business tax by } \\
\text { value-added tax" }\end{array}$ & $\begin{array}{c}\text { the reduced and } \\
\text { of fiscal revenue } \\
\text { after "the } \\
\text { replacement of } \\
\text { business tax by } \\
\text { value-added tax" }\end{array}$ \\
\hline 2005 & 105.56 & 1036.56 & 84.58 & -1015.58 & -253.89 & -1269.47 \\
\hline 2007 & -754.66 & 1531.31 & 95.56 & -2381.53 & -595.38 & -2976.91 \\
\hline 2010 & 651.63 & 2880.93 & 174.76 & -2404.06 & -601.01 & -3005.07 \\
\hline
\end{tabular}

The policy reduces the revenue of the government circulation tax: Theoretically, after the publicity of "the replacement of business tax by value-added tax" in the construction industry, the input VAT through the deduction of fixed asset investment and intermediate cost can reduce the payable tax by enterprises in the construction industry, their extra education tax and city maintenance tax and also the government's circulation tax revenue. Table 2 and 3 suggest the decrease of the total value of output in China's construction industry from 3455.210 billion yuan in 2005 to 9603.113 billion yuan in 2010. Directly related to this, the amount of circulation tax reduction after "the replacement of business tax by value-added tax" increased from -101.558 billion yuan in 2005 to -240.406 in 2010.

It helps increase downstream enterprises' VAT to deduct other taxes: After "the replacement of business tax by value-added tax" in the construction industry, taxpayers can use the VAT engendered in the commodity or labor purchase process to deduct the input tax, which would reduce the amount of payable VAT for purchasers and cut the government's tax revenue with the amount of taxpayers' output tax remaining unchanged. Table 3 suggests that with the improvement and publicity of VAT deduction policy, "the replacement of business tax by value-added tax" in the construction industry had created an increasing amount of deductible input tax for downstream enterprises from 2005 to 2010 , up by $106.62 \%$ from 8.458 billion yuan to 17.476 billion yuan.

It cuts the amount of payable business income tax for enterprises in the construction industry: According to Table 3, the calculation of enterprises' taxable income changed after "the replacement of business tax by value-added tax" in the construction industry: the payable business income tax decreased while the after-tax profits went down accordingly. This is due to the changes in accounting calculation. A point worth paying attention to is that the reduction of the amount of the amount of taxable income make the tax preference policy for the small and micro businesses accessible to enterprises on the sideline(amount of taxable income being 300000 yuan), and the tax reduction policy will go even deeper. 
All in all, "the replacement of business tax by value-added tax" will inevitably bring about changes in enterprises' tax burden in the construction industry. The fruit of reforms will generally relieve enterprises' tax burdens.

Analysis of Difficulties in Carrying out "The Replacement of Business Tax by Value-Added Tax" Policy in China's Construction Industry. The setting of tax rates: The tax rate is an important indicator of the realization of concrete relief of enterprises' tax burdens in the construction industry through "the replacement of business tax by value-added tax". An excessively high tax rate will throw cold water on the enthusiasm of enterprises; while an excessively low tax rate will greatly cut the government's fiscal revenue. An irrational setting of VAT rate will violate the initial intention of reforms and damage the nationwide publicity of "the replacement of business tax by value-added tax" in the construction industry.

The designation of tax payment places: In accordance with the provisions of the current business tax, the tax payment places should be where taxable services take place; the tax liability arising place should be where the agency locates if taxpayer's contracted work covers different provincial administrative regions at the same time. However, considering that the programs in the construction industry are large in size and takes a long time to complete with a strong flow-ability, there are more cross-provincial and subcontracted businesses undertaken by taxpayers. As a result, we need think twice before the designation of tax payment places after "the replacement of business tax by value-added tax" in the construction industry. If the taxable services take place where the tax payment places are, there will be a crying need for the improvement of enterprises' accounting ability. Whereas many of the temporary project department established by construction enterprises are short of sufficient accounting skills [5]. The selection of construction enterprise sites as the tax payment places would make it difficult for the tax authorities to collect taxes and supervise the construction progress and financial situation of projects in another city or region. This will damage the implementation of supervision and regulation works and make it possible for tax evaders to evade taxes.

The deduction of the input tax: At present, the tertiary companies included in VAT pilot programs are so limited while construction enterprises' intermediate costs are not included in the taxable scope of VAT. If "the replacement of business tax by value-added tax" is implemented solely in the construction industry without a deduction chain connecting upstream and downstream enterprises, the tax burdens borne by the construction industry will increase in intensity. Besides, being labor-intensive enterprises, the construction enterprises are confronted with an increasing labor cost in recent years which takes up a large share in their whole costs. But in accordance with the current VAT regulations, the labor cost cannot deduct the input taxes.

The deadline of the deduction of input taxes also brings challenges to the input tax deduction in the construction industry after "the replacement of business tax by value-added tax".

Increasing difficulty in tax authorities' supervision and regulation: The implementation of "the replacement of business tax by value-added tax" in the construction industry of high flow-ability and product complexity would absolutely set higher requirements for various tax authorities' management levels for it is difficult to do cost and profit accounting and strike a balance between different information, which caused more tax evading practices.

\section{Policy Proposals}

Prompt Adjustments of the Current Fiscal Distribution System. At present, business tax and VAT co-exist in China. "The replacement of business tax by value-added tax" in the construction industry will greatly cut the local government's fiscal revenue and redistrict the taxation right of central and local tax authorities. Therefore, to make this reform healthier and run in a more orderly manner, the government should redistrict the taxation right of central and local tax authorities, adjust the interests distribution system of the local government and restructure the ratio at which the tax revenue is shared so as to increase local governments' share of interests and improve the compatible system of fiscal capacity and governance competence in central and local governments. 
Proper Designations of VAT Liability Places in the Construction Industry. Tax liability places should still be where the taxable services take place within the project period; Tax liability places should be where the agency locates if taxpayer's contracted work covers different provincial administrative regions at the same time. This will both avoid the emergence of tax evaders and convenience the construction enterprises to do accounting and to supervise their projects' progress and financial situation.

Extend the Pilot Programs of "The Replacement of Business Tax by Value-Added Tax" to More Regions and Industries. At present, the small number of industries within the pilot scope of "the replacement of business tax by value-added tax", the big number of upstream and downstream construction enterprises involved, the great share of labor values of industries excluded by the reform, both input and output labor, as well as the blocked VAT deduction avenue make these tax burdens to be solely borne by construction enterprises, therefore increase enterprises' costs. So, the government should continue extending the pilot programs of "the replacement of business tax by value-added tax" to more regions and industries and strive to open up the VAT deduction chain of upstream and downstream construction enterprises. Only by this way, can the tax burdens be passed on effectively and can the tax reduction effects be achieved in the whole tax system so as to radically promote the healthy and coordinated development of the construction industry.

Strengthen the Regulation of VAT Collection and Improve Management Level. Due to their low management level of finances and businesses, China's construction enterprises are quite inexperienced in terms of VAT invoice management. As a result, the government should adopt measures accordingly to intensify the regulation of VAT collection, to improve the management level and to create a favorable tax payment environment for "the replacement of business tax by value-added tax" in the construction industry. (1) Intensify the management of VAT invoice and the supervision over the exclusive invoices drawn up by tax authorities for small-amount tax payers. (2) Promote the coordination and cooperation between central and local tax authorities so as to further standardize the management of tax collection. Informationalize the tax collection and management system, integrate the operations of central and local tax authorities and promote information sharing; adjust the scopes of responsibility of central and local authorities, share and exchange information on a regular basis; properly promote the integration of the administration of tax service halls of central and local tax authorities so as to lower taxes according to costs and encourage the enthusiasm of legal tax payers.

\section{References}

[1] J. B. Wen. The government work report, Xinhua News Agency, 2010.3.5. http//www.gov.cn/2010h/content_1555767.htm (Language: In Chinese).

[2] CCCPC's advice on the formulation of the twelfth five-year plan for national economic and social development. Xinhua News Agency, 2010.10.27 (Language: In Chinese).

[3] H.s. Rosen and T. Gayer: Public Finance [M] (China Renmin University Press, 2009 (9)), p.238.

[4] Investment Research Institute and National Development and Reform Commission: Fixed Assets Investment Division, the National Bureau of Statistics China's tertiary industry statistical yearbook, 2010 [M] (Beijing: China Planning Press, 2011) (Language: In Chinese).

[5] C.Yuan: The Fiscal Revenue Impact under Caused by Replacing The Business Tax with a Value - added Tax on Construction Industry in China [J] (MS. Xiamen University, China 2014), p.18 (Language: In Chinese). 